\section{Infectious Mononucleosis}

SIR,-The "new look" at infectious mononucleosis by Dr. H. Pullen (12 May, p. 350), though certainly including much sound clinical information, hardly justifies the epithet "new."

The very brief, almost scathing, reference to the possible aetiological role of E.B. virus will, for example, have disappointed those seeking recent information. Even a brief consideration of the past four years' work on this virus could have provided plausible reasons for some of the observations left unexplained under the headings of "Infectivity" and "Transmission."

Much information which was already available $^{1}$ at least four years ago is omitted entirely from the article. The disease, for instance, is stated not to be notifiable, yet there are figures for notification in Northern Ireland and in Bristol covering several years. The often observed preponderance of the disease in females in the 15-20-year age group is not mentioned. Not all agree that the atypical mononuclear cells of rubella are indistinguishable from those of infectious mononucleosis (and I feel that malaria is over-emphasized as a cause for the appearance of atypical cells). Many would stress that the persistence of the atypical cells in infectious mononucleosis, a feature not mentioned in the article, is at least as importan a diagnostic point as their numbers. With regard to serology, Dr. Pullen does not mention the anti-i antibody, nor the now widely used rapid slide "spot tests" introduced by Davidsohn and his colleagues. ${ }^{2}$ The correct title of the older Paul-Bunnell-Davidsohn test was pleasing to see, but I have Davidsohn's support in rejecting the idea of a titre of $1 / 40$ being necessary for a "positive diag nosis" - no one has yet associated lowe titres of appropriately absorbed sheep cell agglutinins with any other disease. The status of seronegative cases is not discussed, nor the importance of the timing of either serological or haematological tests in relation to the duration of illness.

Dr. Pullen is known to have a special interest in the rashes of infectious mononucleosis. ${ }^{3}$ I wonder if he has the impression, as I have, that rash and jaundice occur together more often than by chance? He leaves the incidence of obvious jaundice vague; would he agree with a figure of about $5 \%$ ?

Marrow depression is given in the article as the cause of agranulocytosis in infectious mononucleosis. These cases are exceedingly rare and relevant information is correspondingly meagre. But milder granulocytopenia is relatively common, and in these cases the evidence favours peripheral granulocyte destruction $^{4}$ with marrow hyperplasia. The absence of marrow depression has been clearly documented by Carter, ${ }^{45}$ whose views on the bone marrow you have recently misquoted, ${ }^{6}$ so misleading others such as Drs. J. F. Boyd and D. Reid (21 April, p. 176).-I am, etc.,

\section{Hugh Penman}

\footnotetext{
Crawley Hospital

Crawley, Sussex

1 Carter, R. L., and Penman, H. G., eds., Infectious Mononucleosis. Oxford, Blackwell, 1969. Lee, C. L., Davidsohn, I., and Panczyszyn, O., American Fournal of Clinical Pathology, 1968,

49, 12.
Pullen, H., Wright, N., and Murdoch, J. McC.,

4 Carter, R. L., Fournal of Clinical Pathology, 1966,

19, 279.
}

5 Carter, R. L., Proceedings of the Royal Society of Medicine, 1969, 62. 1282.
British Medical fournal, 1973, 1, 757.

4 Widmer, L. K., Plechl, S.-C., Leu, H. J., and Boner, H., Schweizerisch

\section{Varicose Veins in the Tropics}

SIR,-Mr. M. A. Hassan and others (3 March, p. 515) refer to the general belief that the incidence of venous disorders among the people of the developing countries of Africa is low. If the data on which this belief is based are studied in respect of varicose veins it is seen that the information comes from "occasional" observations by general practitioners or in hospital notes. The observations in the first case are found in published articles referred to as "personal communications," not available for critical examination, ${ }^{1}$ and in the second they are based on case histories taken for other reasons, the patients usually being bedridden. ${ }^{2}$ It is therefore not surprising that in a special survey of this problem in an African country the prevalence of varicose veins was found to be quite different from the $1 \%$ or less reported by earlier authors.

In February 1972, owing to the kindness of the Ministry of Health and the Service des Grandes Endémies of the Mali Republic we were able to visit 10 traditional villages about $100 \mathrm{~km}$ south of Bamako and quite untouched by occidental medicine. We examined all the women (a total of 469) for the presence of varicose veins, using wellstandardized criteria and methods. ${ }^{3}{ }^{4} \mathrm{Al}$ were examined in the standing position. Their weight, height, number of living children and number of births were noted. Owing to the lack of recent official records ages had to be estimated, and the women were divided into three age groups: (1) young, (2) middleaged, and (3) old. There were 237 in group (1), 166 in group (2), and 66 in group (3). Only evident or "clinical" varicose veins were recorded (see table). "Reticular" varicose veins were dilatations of large subcutaneous veins which did not concern the main saphenous trunks.

The prevalence rate of $10.9 \%$ (all type of varicose veins) in these women was therefore much higher than we were led to expec from the rèports of others. It rose significantly $(P<0.001)\left(\chi^{2}\right.$ test $)$ through the age groups, and the proportion of cases in which the large compared with the small saphenous vein was affected was greater than in European cases. Finally, though $4.5 \%$ of the cases in our series were severe, we never found signs of chronic venous insufficiency or any other complication usually associated with the most severe varicose veins in Europe.-I am, etc.,

A. Rougemont

U.E.R. de Médecine et de Santé Tropicales, 84 rue de Lod Marseille (6e)

1 Burkitt, D. P., British Medical fournal, 1972, 2,

Dodd, H., Lancet, 1964, 2, 809. Guberan, E., et al., Vasa Zeitschrift für Gefäs-
skrankheiten, 1973, 2, 115.

Number and Percentage of Cases of Varicose Veins among 469 Women in Three Age Groups

\begin{tabular}{|c|c|c|c|c|c|}
\hline $\begin{array}{l}\text { Veins } \\
\text { Affected }\end{array}$ & & $\begin{array}{c}\text { (1) Young } \\
(\mathrm{n}=237(50 \cdot 5 \%))\end{array}$ & $\begin{array}{l}\text { (2) Middle-aged } \\
(\mathrm{n}=166(35 \cdot 4 \%))\end{array}$ & $\begin{array}{c}\text { (3) Old } \\
(\mathrm{n}=66(14 \cdot 1 \%))\end{array}$ & $\begin{array}{c}\text { All } \\
(n=469(100 \%))\end{array}$ \\
\hline $\begin{array}{l}\text { Large saphenous .. } \\
\text { Small saphenous } \\
\text { Subcutaneous } \\
\text { ("Reticular") .. }\end{array}$ & $\begin{array}{l}\cdots \\
\cdots \\
\cdots\end{array}$ & $\begin{array}{c}2(0.8 \%) \\
-12(5 \cdot 1 \%)\end{array}$ & $\begin{aligned} & 5(3 \%) \\
& 2(1 \cdot 2 \%) \\
& 17(10 \cdot 2 \%) \\
&\end{aligned}$ & $\begin{array}{l}(1.7 \%) \\
3(4 \cdot 6 \%) \\
9(13 \cdot 6 \%)\end{array}$ & $\begin{array}{r}8(1 \cdot 7 \%) \\
5(1.1 \%) \\
38(8.1 \%) \\
\end{array}$ \\
\hline Total & . & $14(5 \cdot 9 \%)$ & $24(14 \cdot 4 \%)$ & $13(19 \cdot 9 \%)$ & $51(10 \cdot 9 \%)$ \\
\hline
\end{tabular}

\section{Adrenal Failure in Bronchial Asthma}

SIR,-The beclomethasone dipropionate aerosol has been introduced into the treatment of bronchial asthma with a recommendation that the majority of patients on systemic steroids can be converted to its use with reduction or discontinuation of the oral dose. We believe this to be a potentially dangerous policy and would like to support the fears of Dr. J. C. Batten and his colleagues (3 February, p. 296) with the following case report of a patient recently under our care.

A man aged 37 with a 30 -year history of bronohial asthma had received 5-15 $\mathrm{mg}$ of prednisolone daily for four years. Adrenal function was known to be deficient, with a basal plasma cortisol level of $4.5 \mu \mathrm{g} / 100 \mathrm{ml}$ which reached only $8.5 \mu \mathrm{g} / 100 \mathrm{ml} 60$ minutes after $250 \mu \mathrm{g}$ of tetracosactrin intramoon face, striae, muscle wasting, and osteoporosis. For these reasons he was started on treatment with a beclomethasone inhaler and the dosage of prednisolone reduced in one month from $15 \mathrm{mg}$ to $7.5 \mathrm{mg}$ daily, without deterioration in respiratory function. The dosage was maintained at this level so that he was not bereft of systemic steroid.

He developed, at home, "viral" gastroenteritis for which he received symptomatic treatment from his family doctor. This appeared to be a mild illness. There were no signs of adrenal insufficiency and no obvious hours after consulting his doctor he died suddenly. At necropsy the cause of death was recorded as right lower lobe pneumonia. Both adrenal glands were small and atrophic. There was no evidence of myocardial infarc tion or cerebrovascular accident. Adrenal failure, we feel, could have contributed to this patient's sudden death

Patients with adrenal suppression due to steroid therapy may be at considerable risk during the stress of an intercurrent illness when oral steroids have been reduced or discontinued in favour of beclomethasone aerosol.-We are, etc.

\section{Ruth M. Cayton} PETER HOWARD

University Department of Medicine, Sheffield

\section{Cognitive Deficits in Parkinsonism}

SIR,-In your leading article on mental symptoms and Parkinsonism (14 April, p. 67) the important question of dementia was mentioned apropos of discussion of evidence reported by Celesia and Wanamaker. ${ }^{1}$ I should like to raise some further points on this topic, venously. In addition he was obese, with a deterioration in his respiratory condition. Six 